\title{
The Precautionary Principle as a Basis for Decision Making
}

\section{Citation}

Cass R. Sunstein, The Precautionary Principle as a Basis for Decision Making, 2 Economists' Voice 1553 (2005).

\section{Published Version}

http://www.degruyter.com/view/j/ev.2005.2.2/ev.2005.2.2.1079/ev.2005.2.2.1079.xml?format=INT

\section{Permanent link}

http://nrs.harvard.edu/urn-3:HUL.InstRepos:29998410

\section{Terms of Use}

This article was downloaded from Harvard University's DASH repository, and is made available under the terms and conditions applicable to Open Access Policy Articles, as set forth at http:// nrs.harvard.edu/urn-3:HUL.InstRepos:dash.current.terms-of-use\#OAP

\section{Share Your Story}

The Harvard community has made this article openly available.

Please share how this access benefits you. Submit a story.

Accessibility 


\title{
The Economists' Voice
}

Volume 2, Issue 2

2005

Article 8

\section{The Precautionary Principle as a Basis for Decision Making}

\author{
Cass R. Sunstein*
}

\begin{abstract}
Summary
Over the coming decades, the increasingly popular "precautionary principle" is likely to have a significant impact on policies all over the world. Applying this principle could lead to dramatic changes in decision making. Possible applications include climate change, genetically modified food, nuclear power, homeland security, new drug therapies, and even war.

We argue that the precautionary principle does not help individuals or nations make difficult choices in a non-arbitrary way. Taken seriously, it can be paralyzing, providing no direction at all. In contrast, balancing costs against benefits can offer the foundation of a principled approach for making difficult decisions.
\end{abstract}

KEYWORDS: precautionary principle, cost-benefit analysis

*University of Chicago

Copyright $\mathrm{c} \bigcirc 2005$ by the authors. All rights reserved. 


\section{Introduction}

Over the coming decades, the increasingly popular "precautionary principle" is likely to have a significant impact on policies all over the world.

The simplest interpretation of the precautionary principle is that "it is better to be safe than sorry." But the principle comes in many diverse forms, ranging from weak to strong. One scholar counted nineteen.

An example of a strong form is the influential Wingspread Declaration, produced in a meeting of environmentalists in 1998: "When an activity raises threats of harm to human health or the environment, precautionary measures should be taken even if some cause and effect relationships are not fully established scientifically."

The European Union has taken a leadership role in promoting the precautionary principle as a basis for making decisions on environmental policy and other areas, such as trade. The EU has not specified the version of the principle that it would like to use in particular settings. But it has clearly endorsed the general idea that regulatory action should be taken even when harm cannot be established, and indeed even when it is highly speculative.

Applying this principle, in any of its forms, could lead to dramatic changes in decision making. Possible areas in which it might be applied include climate change, genetically modified food, nuclear power, pesticides, cell phones, homeland security, new drug therapies, and even war.

For this reason, serious thought needs to be given to the strengths and weakness of adopting this principle before using it to help make difficult decisions.

\section{Why It's Not Always Better to Be Safe than Sorry}

Even the simplest interpretation of the precautionary principle-that "it is better to be safe than sorry"-raises complex questions.

To begin, an essential dilemma for policy makers is that it is not clear what to do if one wants to be "safe." How safe is safe enough? Without

\footnotetext{
${ }^{1}$ Wingspread Statement on the Precautionary Principle, available at http://www.gdrc.org/ugov/precaution-3.html.
} 
considering the costs of providing safety, it is virtually impossible to answer this question.

For those who favor taking regulatory precautions, the conceptual difficulty is even worse. Risks, sometimes unforeseen, can arise from action as well as from inaction; consider the war in Iraq. And reducing risks in one policy domain (say, the environment) could increase risks in another (say, defense)especially when resources are scarce.

A key problem with strong versions of the precautionary principle is that they are logically inconsistent. They would frequently eliminate all policies from consideration-inclding the status quo — because almost all policies impose risks of one kind or another.

\section{A Few Examples of How All Policies-Even Precautionary Ones-Impose Risks}

To understand the difficulty, consider some examples.

Genetic modification of food has become a widespread practice. The risks of that practice are not known with any precision. Some people fear that genetic modification will result in serious ecological harm and large risks to human health; but others believe that genetic modification will result in more nutritious food and significant improvements in human health.

Many people fear nuclear power, on the grounds that nuclear power plants create various health and safety risks, including some possibility of catastrophe. But if a nation does not rely on nuclear power, it might well rely instead on fossil fuels, and in particular on coal-fired power plants. And such plants create risks of their own, including risks associated with global warming. At the same time, nuclear energy may actually decrease environmental risks: China, for example, has relied on nuclear energy, in a way that reduces greenhouse gases and a range of air pollution problems.

In the early years of the Bush Administration, one of the most controversial environmental issues involved the regulation of arsenic in drinking water. There is a serious dispute over the precise level of risks posed by low levels of arsenic in water, but taking the worst-case scenario, over one hundred lives might be lost each year as a result of the original, 50-part-per-billion standard that the Clinton Administration sought to revise. At the same time, 
however, the proposed ten-part-per-billion standard could cost over \$200 million each year, and it is possible that it would save as few as six lives annually.

In these cases, what kind of guidance is provided by the precautionary principle? It is tempting to say that the principle calls for strong controls on genetic engineering of food, on nuclear power, and on arsenic. After all, in each of these cases, there is a possibility of serious harms. Genetically modified foods, for example, seem like a core area in which to apply the Wingspread Declaration, as there are threats of harm (not fully proven) to human health and the environment.

But so applied, is the precautionary principle really helpful? The answer, in each of these cases, is that it is not. One reason is that regulation might well deprive society of significant benefits, and hence produce serious harms that would otherwise not occur.

In some cases, regulation eliminates the benefits of a process or activity, and thus causes preventable deaths. If this is so, then regulation is hardly precautionary; indeed, it violates the precautionary principle.

The problem is not limited to these examples. It is quite general.

Consider, for example, the U.S. Environmental Protection Agency's precautionary decision to ban almost all uses of asbestos. That decision was invalidated in federal court, in part, on the ground that in some contexts, the alternatives appear to create larger risks than asbestos itself does.

In the court's words, "the EPA cannot say with any assurance that its regulation will increase workplace safety when it refuses to evaluate the harm that will result from the increased use of substitute products" - especially since "many of the substitutes that EPA itself concedes will be used in place of asbestos have known carcinogenic effects."

\footnotetext{
${ }^{2}$ Corrosion Proof Fittings v. EPA, 947 F.2d 1201 (5 $5^{\text {th }}$ Cir. 1991).
} 


\section{The Necessity of Considering All Relevant Risks-Not Just Those Lessened by Regulation}

These examples suggest that regulation sometimes violates the precautionary principle because it gives rise to other risks, in the form of hazards that materialize, or are increased, as a result of regulation.

Consider the drug approval process. If a government takes a highly precautionary approach to the introduction of new medicines and drugs onto the market, it will protect people against harms from inadequately tested drugs; but it will also prevent people from receiving potential benefits from those very drugs.

Of course, the proper approach to new drugs is much disputed. But the precautionary principle cannot help to answer a key question within this inquiry: What is the appropriate level of pre-market testing?

If the strong version of the precautionary principle is taken seriously, extensive regulatory requirements are both required and forbidden. Would it not be better to ask whether any particular approval process creates benefits, through preventing iatrogenic illness, that exceed the costs of unavailable medications and foregone innovation?

\section{Regulation Typically Creates New Risk Profiles, Rather than Simply Lessening Risk}

It turns out that the danger that regulation will create new or different risk profiles is the rule, not the exception.

In the case of arsenic, the Administrator of the Environmental Protection Agency expressed concern that aggressive regulation, by virtue of its cost, will lead people to cease using local water systems and to rely on private wells, which have high levels of contamination. If this is so, then stringent arsenic regulation violates the precautionary principle, for the same reason that less stringent regulation does.

The issue is compounded by the fact that regulations and policy interventions use scarce resources. A great deal of empirical work suggests that an expensive regulation can have adverse effects on life and health. It has been 
argued, for example, that a statistical life can be lost for an expenditure of between $\$ 7$ to $\$ 15$ million. $^{3}$

We do not mean to accept any particular amount here, or even to suggest that there has been an unambiguous demonstration of an association between mortality and regulatory expenditures. Rather, for purposes of evaluating the precautionary principle, with its attempt to prevent even speculative harm, our only point here is that reasonable people do believe in that association.

This tradeoff between wealth and health makes the precautionary principle hard to implement not merely where regulation removes benefits, or introduces or increases other risks, but in any case in which the regulation costs a significant amount.

For this reason, the precautionary principle raises doubts about many expensive regulations. The most general point is that, the precautionary principle is frequently paralyzing: It can stand as an obstacle to regulation and nonregulation, and to everything in between.

\section{Privileging Existing Risks over New Risks Makes Little, If Any, Sense}

Advocates of the principle might be able to find ways out of this dilemma. For example, they could say that new risks are unacceptable, but existing risks are fine. And, indeed, a bias in favor of existing risks does seem to animate many uses of the precautionary principle.

But that bias is hard to defend in principle. By its logic, we would never have accepted electricity, the automobile, the Internet, or countless other inventions that allow our modern society to function-but that impose risks. (Alternatively, one could embrace all new risks and scoff at existing risks-but that would lead to an equally troubling result, leading us to accept even very highly risky innovations with little benefit.)

Or one could say that the precautionary principle will be applied to the risks that are most salient or of most concern to the public-and that the less salient or visible risks will be ignored. And in fact, the precautionary principle often seems motivated by this form of selectivity_favoring the kind of risks that

\footnotetext{
${ }^{3}$ Ralph Keeney, Mortality Risks Induced by Economic Expenditures, Risk Anal. 10, 147 (1990). R. Lutter, J. Morrall, and W. K. Viscusi, The Cost-per-Life Saved Cutoff for Safety-Enhancing Regulations, Economic Inquiry 37, 4: 599-608. (1999).
} 
cause tragedies that make headlines, while ignoring the kind that show up only as a result of statistical analysis.

But why would that be sensible? Isn't a death or illness that occurs quietly, as a result of, say, a cumulative risk, just as important as a death or illness that occurs in a spectacular fashion that makes news? Subtle causation is no less deadly.

These points help to identify another problem. The precautionary principle does not provide guidance on how much to regulate; it does not easily allow for weighing the variables that are at stake.

It leaves questions like these unanswered: How does one account for tradeoffs between present and future risks? How should we weigh expenditures on reducing particulate matter against the possible loss in resources available for food or health care? Does one value a life today more than one tomorrow? Without helping to answer such questions, the principle is not useful.

\section{The Need To Balance Benefits and Costs}

We do not believe there is any principled way of making policy decisions without making the best possible effort to balance all the relevant costs of a policy against the benefits. Looking only to costs, and ignoring benefits, is always a mistake.

Of course, the proper cost-benefit analysis can and should incorporate concerns about precaution. For example, a problem characterized by irreversibilities - such as the persistence of certain chemicals in the atmosphere that deplete the ozone layer-can be modeled using standard techniques in costbenefit analysis. Uncertainties about both benefits and costs can also be incorporated, perhaps by specifying a range of possible outcomes, perhaps by seeking to preserve specified options, or perhaps by identifying the worst-case scenario and showing a degree of risk aversion with respect to that scenario.

In some cases, the balancing of benefits and costs will be easy. In others, it will be hard to quantify benefits-as, for example, in the case of regulations designed to protect against terrorism, where it is hard to assign probabilities to various outcomes. 
But even these hard cases should not excuse decision makers from at least attempting to make quantitative estimates of the costs of various options.

\section{The Fallacy of Believing We Can Live Risk-Free}

The fact is, even in the case of terrorism and other hard cases, societies cannot afford to seek totally risk-free environments. If they try, they might well magnify the problems they face.

For example, governments do not ban air travel, even though such bans would eliminate a possible source of terrorist attacks. An intuitive benefit-cost analysis suggests that the costs of banning air travel would greatly outweigh the benefits.

For terrorism, climate change, and other vexing problems, hard choices must be made. The precautionary principle does not help individuals or nations to make such choices in a non-arbitrary way.

Indeed, taken seriously, the precautionary principle can be paralyzing, providing no direction at all. Balancing costs against benefits ought not to be understood as a way of placing regulators into an arithmetic straightjacket. But it does offer the foundation of a principled approach for making difficult decisions.

Robert Hahn is co-founder and executive director of the American Enterprise Institute-Brookings Joint Center, which focuses on regulation and antitrust. He is the author of In Defense of the Economic Analysis of Regulation (AEI-Brookings, 2005), which was recently written up in the Economist. In addition, Dr. Hahn is co-founder of the Community Preparatory School-an inner-city middle school in Providence, Rhode Island, that provides opportunities for disadvantaged youth to achieve their full potential.

Cass R. Sunstein is Karl N. Llewellyn Distinguished Service Professor at the University of Chicago Law School; for part of 2005-2006, he will be Visiting Professor at Harvard Law School. His publications include Risk and Reason (2002), Punitive Damages: How Juries Decide (with several coauthors, including W. Kip Viscusi); The Second Bill of Rights (2004); and Laws of Fear: Beyond the Precautionary Principle (2005). 
Letters commenting on this piece or others may be submitted at

\section{References and Further Reading}

Arrow, K.J., et al., "Is There a Role for Benefit-Cost Analysis in Environmental, Health, and Safety Regulation?” Science, No. 272 (1996), pp. 221-222.

Arrow, K.J. and A. Fisher, "Environmental Preservation, Uncertainty, and Irreversibility," The Quarterly Journal of Economics, Vol. 88, No. 2 (1974), pp. 312-319.

European Commission, Communication from the Commission on the Precautionary Principle, Brussels: The Commission of the European Communities (2000).

Graham, J. and S. Hsia, "Europe's Precautionary Principle: Promise and Pitfalls," J. of Risk Res., Vol.5, No. 4, (2002), p. 380.

Graham, J. and J. Wiener, ed., Risk vs. Risk: Tradeoffs in Protecting Health and the Environment, Harvard University Press (Oct., 1995).

Lave, L. "The Strategy of Social Regulation: Decision Frameworks for Policy," Washington DC: The Brookings Institution (1981).

Peltzman, S. "An Evaluation of Consumer Protection Legislation: The 1962 Drug Amendments," Journal of Political Economies, Vol. 81 (1973), pp. 1049-91.

Office of Management and Budget, Report to Congress on the Costs and Benefits of Federal Regulations, available at http://www.whitehouse.gov/omb/fedreg/2003draft_cost-benefit_rpt.pdf, (2003), p. 84.

Sandin, P. "Better Safe than Sorry: Applying Philosophical Methods to the Debate on Risk and the Precautionary Principle," Stockholm (2004), available at http://www.infra.kth.se/ sandin/dissintro.pdf.

Sandin, P. "Dimensions of the Precautionary Principle," Human and Ecology Risk Assessment, Vol. 5 (1999), pp. 889-907. 
Sunstein, C. "The Arithmetic of Arsenic," Georgetown L. Rev., Vol. 90 (2002), p. 2255.

Sunstein, C., Laws of Fear: Beyond the Precautionary Principle, Cambridge University Press (2005).

Stewart R. "Environmental Decision-Making Under Uncertainty," Res. in Law and Econ., Vol.71 (2002), p. 76.

Wildavsky, A. Searching for Safety, New Brunswick, New Jersey: Transaction Books (1988).

Wildavsky, A. "Richer is Safer," The Pub. Interest, Vol. 60 (1980), p. 27-29.

Wiener, J. "Comparing Precaution in the United States and Europe," J. of Risk Res., Vol. 5, No. 4, (2002), pp. 317-349.

Zhong, Ling. "Nuclear Energy: China's Approach Towards Addressing Global Warming," Geo. Int'l Envtl. L. Rev., Vol. 12 (2000), p. 493. 